\title{
Rural-Urban Migration among Youths in Nigeria: The Impacts on Agriculture and Rural Development
}

\author{
Yohanna Danladi Pam
}

\begin{abstract}
This article examines the causes of rural-urban migration; its impact on agriculture and rural development and its benefits to rural dwellers. Agriculture is the major source of employment among the rural dwellers in Nigeria. But with the discovery of oil, the attention of the government and other key players shifted to oil, thus neglecting the agriculture sector. This negligence, coupled with lack of basic amenities such as water, electricity, good roads, schools etc.in the rural areas led to massive movement of youths from the rural areas to urban areas in search of white collar jobs. The movement took away able-bodied young men and women from the rural areas leaving behind the aged and children who do not have the capacity to till the land, thus affecting agriculture and rural development. The research was carried out using secondary resources.

The research suggests that government and other stakeholders should invest more on infrastructural development in rural areas. This will reduce rural-urban migration. It is equally suggested that the defunct Agriculture Marketing Board should be revived. This will help farmers to get adequate reward for their farm products. Thus making agriculture attractive to young people and in turn checking the mass movement of youths from rural to urban areas.
\end{abstract}

Key Words: Migration, Agriculture, Rural, Urban, Development, and Youths.

\section{Introduction}

Nigeria is a country with an estimated population of 160 million. Nigeria lies on the west coast of Africa and occupies approximately 923,768 square kilometers of land. It shares borders with Chad, Cameroun and Benin. The spatial distribution of the population is uneven, with majority $(65 \%)$ of it population living in the rural areas and the remaining living in urban areas. With wide varieties of climate, vegetation and soil condition, Nigeria possesses the potential for wide range of agriculture production. Thus, the majority of Nigerians depend on the agricultural sector for employment and survival. Some of the benefits of agriculture to Nigerian economy are the provision of food, employment, raw materials for agro-allied industries, contribution to GDP and generation of foreign exchange. Unfortunately, when oil was discovered, Nigerian's over dependency on the oil sector led to the downfall of the agriculture sector. Despite that, agriculture still remains one of the most viable sectors in the Nigerian economy. The sector employed about $65 \%$ of the total population in Nigeria. Research by Tsigas and Ehui (2006) supports "Agriculture is the backbone of the rural economy, generating about 30 percent of gross domestic product (GDP) and providing by far the largest source of employment." Thus the major occupation of the people in the rural areas in Nigeria is farming, which centers on land cultivation for the production of crops, animal husbandry, poultry, fishing and food processing industries.

\section{Statement of the Problem}

The impact of rural-urban migration among the youths on agriculture and rural development cannot be overemphasized. The rural areas in Nigeria are endowed with both human and material resources, unfortunately, these potentials are yet to be harnessed and used for agricultural and rural development. According to Iruonage (2009), "Useful natural resources, which can be harnessed for socio-economic development, abound in Nigeria particularly in the rural areas." Therefore, the migration of youths from rural areas to cities in search of better life, is taking away the potential youths who are capable of developing the rural areas.

The inequality between the rural and urban areas in the provision of basic facilities is another major factor responsible for rural -urban migration among the youths in Nigeria. Most of the rural areas in Nigeria lack basic amenities such as electricity, water, good roads, clinics and good housing. These usually push the youths to migrate to the urban areas in order to access these amenities. Other challenges faced by the youths in rural areas are, low agriculture productivity and low standard of living. All these factors encouraged the migration of youths from rural to urban centers.

Objectives of the Paper: This paper will examine the causes of rural-urban migration among youths in Nigeria and its impact on agriculture and rural development. The paper will further recommend solutions to the problem. 


\section{Literature Review:}

Concept of Migration: Migration is defined as the movement of people from one place to another in search of employment, market, education, health and other means of livelihood. The movement can be temporary or permanent. They are of the opinion that "Migration occurs as a response to economic development as well as social, cultural, environmental and political factors and effects on areas of origin as destination (Chikaire, Nnadi, Atoma, Egwuonwu, Echetama, 2012).

In Nigeria and many developing countries, there has been rapid growth of cities at the detriment of the rural areas. The rural population is gradually shrinking, while the urban population is blooming. They found that "Nigeria is a typical example of a country, where there had been a tremendous expansion of urban areas consequent to the rapid rural migration (Chikaire et al, 2012, P.1)". The large number of able-bodied men and women moving to the cities is at an alarming rate. The intention of the movement varies; some migrate to the urban centers in search of job, while others migrate to enjoy basic amenities that are lacking in the rural areas. Unfortunately, there is no expansion or improvement on the basic amenities in the cities to meet with the increasing demand of the growing population. Thus, most of the migrants end up in slums, where they compete with each other for survival. As a result, the overcrowded cities suffer the consequences of overstretched few facilities and also increased on crime. The migration also takes away able-bodied young men and women from the rural areas to urban centers, thereby making the rural areas to loss the manpower necessary for agriculture and rural development.

\section{Causes of Migration:}

Absence of basic amenities: lack of basic amenities such as pipe-borne water, electricity, good roads and health facilities are among the major reasons why youths migrate from rural to urban centers. They asserted, "The main source of attraction to the city and their main reason for leaving the village is because of the absence of social amenities (Adesiji, Omoniwa, Adebayo, Matanmi, Akangbe, 2009,P.69)"

Lack of interest in farming: The farming system in Nigeria has remained traditional. Farming is still done through the use of traditional method. The farmers are still using traditional farming implements such as hoes and cutlasses for farming at subsistence level. These make farming difficult, small scale and unrewarding. Thus, making the youths to loss interest in farming and migrate to urban areas in search of better means of livelihood.

Search for education: Most of the rural areas don't have schools and for those who have schools, the schools lack basic teaching and learning facilities and qualified teachers. De Haan argued that "through migration, the capabilities of individuals are improved in view of the fact that the migrant acquires some form of education and brings back home new ideas and new skills which could in some circumstances improve productivity in Agriculture (as cited by Koko and Abdullahi 2012, P.11)". Therefore, Education is a pull factor for the movement of youths to urban centers.

Employment: Due to the concentration of industries, government offices and organizations in the urban centers, youths are moving to urban centers in search of jobs.

\section{Impacts of Migration on Agriculture and Rural Development:}

Low agriculture productivity: The high level of migration among the youths from rural to urban centers in Nigeria has affected food production, thereby causing the problem of food insecurity. The youths who are the productive group in rural areas migrates to urban centers leaving behind the aged and children who are weak and cannot engage in farm work. Thus, agriculture and rural development suffer set back as a result of the youth migration. They found that, "In most rural areas, the impact of rural-urban migration was a rapid deterioration of the rural economy leading to chronic poverty and food insecurity. This arises mainly due to excessive drain of youth from the rural populace thus leaving only the older and aged members to constitute the labor force of the rural area Chikire, et al, 2012, P. 2)". Therefore, for any meaningful development to take place in agriculture and rural areas, they youths who are educated and active need to remain in the rural areas to initiates ideas that will lead to the progress and development of agriculture and rural areas.

Slow down rural development: The educated youths are no longer interested in staying in rural areas. As soon as they acquire their education, they always migrate to the urban centers in search of jobs and to enjoy the basic amenities in the urban centers, which are not available in the rural areas. According to International Fund for Agricultural Development (2007), "Outmigration can also cause the drain of skills and the loss of innovative community members from rural areas (PG.1)". This usually drains the brain from the rural areas that are supposed to initiate progressive ideas for the development of the rural areas.

Loosing traditional values: They youths who migrate to the cities are usually influence by the ways of life of the city. This sometimes makes them to abandon the important cultural values of their communities and take up the 'so called' modern ways of life. This in turn may likely have negative impact on their community. 


\section{Benefits Of Migration}

Remittances: There is a flow of remittances from migrants who moved to the cities to rural areas. These remittances are used to buy fertilizers and other farm inputs. It is also used for paying school fees and medical bills. According to IFAD (2007), "Global remittances, for example, are growing quickly and steadily. In some locations, they have overtaken agriculture as the main source of income for rural households (PG.1)".

Expansion of towns: Migration can lead to expansion of towns. According to IFAD (2007), "The new rural space is characterized by the growth of small towns and medium-size cities with strong economic ties to the rural inhabitants who stay behind (PG.2)" The towns that are expanded as a result of migration can be beneficial to rural areas that are located close to them. The nearby towns can influence agriculture development in the rural areas when most of the foods produced in the rural areas are purchase by the town people. This may influence the development of commercial agriculture in the nearby rural areas.

\section{Data Discussion:}

Table 1. Rate Of Rural-Urban Migration By Age Of The Rural Family Members In Selected Households For The Last 10 Years As At 2010

\begin{tabular}{|c|c|c|}
\hline AGE (YEARS) & NUMBER & MIGRATION RATE (\%) \\
\hline $0-10$ & 16 & 2.4 \\
\hline $11-20$ & 201 & 30.5 \\
\hline $21-30$ & 341 & 51.7 \\
\hline $31-40$ & 60 & 9.5 \\
\hline $41-50$ & 42 & 6.4 \\
\hline Above 50 & 0 & 0.0 \\
\hline
\end{tabular}

Table adopted from Ofuoku and Chukwuji.

This table categorized the rate of rural to urban migration based on age. The figure from the table clearly shows that the rate of migration from rural to urban centers is common among ages 11-20 and 21-30. Therefore about $60 \%$ of the productive youths in the rural areas migrate to urban centers. Thus, they youths who are the most productive group of people in rural areas migrate to the urban centers leaving behind the aged and the children who are about $40 \%$ of the total population in the rural areas. This usually hinders the development of agriculture and rural areas, since the educated and strong individuals who are supposed to initiate progressive ideas are migrating to the urban centers.

\section{Conclusion and Policy Recommendation}

In conclusion, Rural-urban migration is a challenge to agriculture and rural development in Nigeria. Rural-urban migration has taken away the active population of rural areas, leaving behind the children and aged who are not actively engaged in agriculture. But despite the negative impact, rural-urban migration has created an opportunity for migrants to secure non-agriculture jobs and in turn send remittances to their families.

I therefore recommend that, the government of Nigeria should invest more of it resources on rural infrastructure to facilitate the development of non-agro sector of rural areas to reduce migration.

The remittances received by families should be invested in a project that will create jobs and provide sustainable income for families.

Those who migrate to the cities should pull their resources together and embark on a community development projects such as school, health centers, provision of water and other basic facilities that will enhance the development of rural areas.

The Government of Nigeria should partner with the private sector to establish more agro-allied industries or agriculture processing industries in the rural areas in order to provide jobs for the teaming youths who are moving out of the rural areas.

The Government of Nigeria should revive the Agriculture Marketing Board to assist in regulating prices of agricultural products, which will assist the farmers to get good reward for their crops. Thus, making agriculture attractive to the youths.

The Government should work with other stakeholders to encourage mechanize farming is rural areas. This will ease farming work and at the same time expand farming and make it interesting and rewarding to farmers.

The Government should work with the farmers to set up genuine cooperative societies. The cooperative societies should be used as a channel through which government can disburse loans and other farming equipment to local farmers. Using this channel to disburse loans and farm equipment will assist in removing the challenge faced by farmers in accessing government loans, grants and farming equipment. This will in turn help in assisting the young people to access loans and other farm equipment that will make farming interesting to them, thus making them to remain in the rural areas to farm. 
The Government should provide basic amenities such as electricity, water, roads, and educational institutions. This will make the young people to remain in the rural areas to farm.

\section{References}

[1] Adesiji, G.B., Omoniwa, V., Adebayo, S.A., Matanmi, B. M., and Akangbe, J. A. (2009). Factors associated with the youths ruralUrban Drift in Kwara, Nigeria. Interdisciplinary Journal of cotemporary Research in Business, Vol 1, No 8. Retrieved on November 29, 2013 from http://www.unilorin.edu.ng

[2] IFAD (2007). Migration and rural employment. Proceeding of Round Table on migration and rural Employment, in Conjunction with the thirtieth section of IFAD's Governing Council, February 2007. Retrieved on November 29, 2013 from www.ifad.org

[3] Iruonagbe, T. C. (2009). Rural-urban Migration And Agriculture Development in Nigeria. Arts and Social science International Research Journal, Vol 1. Retrievedon November 30, 2013 from www.eprints.convenantuniversity.edu.ng

[4] Koko, I. S. and Abdullahi, D. (2012). Effects of migration of farmers on sustainable Livelihood in Nigeria. IOSR Journal of Business and Management, Volume 3, issue 3. Retrieved on November 30, 2013 from www.iosrjournal.org

[5] Chikaire, J., Nnadi, F.N., Atoma, C., Egwuonwu, H.A., Echetama, J.A. (2012). Rural Youth Empowerment: A panacea to RuralUrban Drift. A case study of Ethiope-East area of Delta State. Science Journal of Sociology and Anthropology, Vol 2012, Article 10. Retrieved December 1, 2013 from http://www.sjpub.org

[6] Ofuoku, A.U. and Chukwuji, C.O. (2012). The impact of Rural-Urban Migration on plantation Agriculture in the Niger-Delta Region, Nigeria. Journal of Rural social science. Retrieved on December 1, 2013 fromwww.ag.auburn.edu 